Удк 616.145.74-007.64-005.1-036:616.36-002-036.1

DOI 10.11603/2414-4533.2021.2.12301

(СМ. В. ТРОФІМОВ, Б. В. ГУЗЕНКО, С. І. БАРАННИК, В. В. ГРОМОВ

Дніпровський державний медичний університет

\title{
Клініко-статистичні аспекти розвитку і перебігу кровотеч із варикозно розширених вен стравоходу в паціентів із хронічним вірусним гепатитом $\mathrm{C}$
}

\begin{abstract}
Мета роботи: визначити особливості перебігу синдрому портальної гіпертензії ускладненого кровотечею з варикозно розширених вен у пацієнтів із хронічним вірусним гепатитом С.

Матеріали і методи. Ми зібрали, обробили і проаналізували результати лікування 46 пацієнтів із кровотечами з варикозно розширених вен стравоходу (ВРВ), госпіталізованих у КНП “Дніпровська клінічна лікарня швидкої медичної допомоги” ДМР” за 2017 р. Основним етіологічним фактором, що призвів до розвитку портальної гіпертензії у даній групі пацієнтів, встановлено цироз печінки на фоні хронічного вірусного гепатиту С (ХВГС). Ступінь крововтрати у даної категорії хворих розподілився так: мінімальна - в 13 випадках (28,3 \%), середня - в 16 (34,8 \%), велика і масивна - в 8 (17,4 \%) і 9 (19,6 \%) відповідно.

Усім пацієнтам проведено оцінку функціонального стану печінки з використанням клініко-лабораторних методів.

Результати досліджень та їх обговорення. Встановлено, що рівень вмісту загального білірубіну в сироватці крові у 22 $(47,8 \%)$ пацієнтів був у межах референсних показників, перевищення рівня менш ніж у 2 рази встановлено в 14 хворих (30,4 \%), в 10 випадках (21,7 \%) виявлено підвищення рівня білірубіну більш ніж у 2 рази.

Аналіз рівня трансфераз у хворих на ХВГС, що ускладнився кровотечею з ВРВ, встановив показники АЛТ у межах референсних значень у 29 випадках (63,1 \%), підвищення показника менш ніж у 2 рази $\left(\mathrm{n}_{2}\right)$ - у 12 випадках $(26,1 \%)$, більш ніж в 2 рази підвищення рівня трансферази встановлено в 5 випадках (10,8 \%).

Проведено оцінку печінкової недостатності за класифікацією Чайлд-П’ю. Недостатність ступеня А встановлено у 23 пацієнтів (50 \%), ступінь В - у 16 (34,8 \%), ступінь С - у 7 (15,2 \%).

У результаті проведеного лікування 36 хворих (78,3 \%) виписали з поліпшенням, в 10 епізодах (21,7 \%) спостерігали летальний результат.
\end{abstract}

Ключові слова: хронічний вірусний гепатит С; варикозно розширені вени стравоходу; кровотеча з верхніх відділів шлунковокишкового тракту; портальна гіпертензія.

Постановка проблеми і аналіз останніх досліджень та публікацій. Кровотечі з варикозно розширених вен (ВРВ) стравоходу на сьогодні $\epsilon$ однією $з$ актуальних проблем сучасної хірургії. Так, смертність від вперше виниклих кровотеч із варикозно розширених вен стравоходу, за сучасними даними, коливається від 15 до 84 \% [1, 2].

Флебоектазії стравоходу є портосистемні колатералі, що формуються внаслідок розвитку портальної гіпертензії - прогресуючого ускладнення цирозу печінки. У пацієнтів із цирозом печінки частота розвитку варикозного розширення вен стравоходу варіює в межах від 30 до 70 \%. Одним із провідних етіологічних чинників розвитку цирозу печінки є хронічний вірусний гепатит С [3, 4]. За даними ВООЗ в Україні 8 \% населення інфіковане вірусом гепатиту C.

Мета роботи: визначити особливості перебігу синдрому портальної гіпертензії ускладненого кровотечею з ВРВ у пацієнтів із хронічним вірусним гепатитом C.

Матеріали і методи. Аналіз випадків кровотеч із ВРВ у пацієнтів, госпіталізованих у КНП
“Дніпровська КЛШМД”ДМР”, встановив, що за 2017 рік перебувало на лікуванні 95 осіб. Етіологічними факторами портальної гіпертензії, які призвели до кровотечі з ВРВ, були: синдром портальної гіпертензії - 1 (1,1 \%), рак печінки - 2 (2,1%), цироз печінки - 92 випадки (96,8 \%). При цьому в 46 випадках (48,4 \%) цироз печінки розвинувся на фоні хронічного вірусного гепатиту C (ХВГС).

Обробку даних провели з використанням статистичних програм і методів: загальноклінічних езофагогастродуоденоскопія (ЕГДС) з визначенням локалізації, ступеня виразності ВРВ і стану місцевого гемостазу; лабораторних - загальний клінічний аналіз крові з визначенням рівня гемоглобіну, кількості еритроцитів, біохімічний аналіз крові - динаміка рівня білірубіну, АЛТ [5]; методи статистичної обробки даних та їх аналізу - критерію достовірності (р) Стьюдента з використанням програмного забезпечення Microsoft Access 2019, Microsoft Excel 2019 (00414-65322-08041-AA945).

Як контрольні показники білірубіну та рівня трансфераз ми використовували дані обстеження групи 45 здорових добровольців. 
Результати досліджень та їх обговорення. Проаналізовано 46 медичних карт стаціонарних хворих за 2017 р. Встановлено, що у пацієнтів, у яких розвиток ВРВ пов'язано з прогресуванням ХВГС на момент госпіталізації в стаціонар, зазначалася активна кровотеча в 11 випадках (23,9 \%), що зупинилася в 35 (76,1%) (рис. 1).

Проведено оцінку крововтрати за класифікацією Американської колегії хірургів (за Р. L. Marino

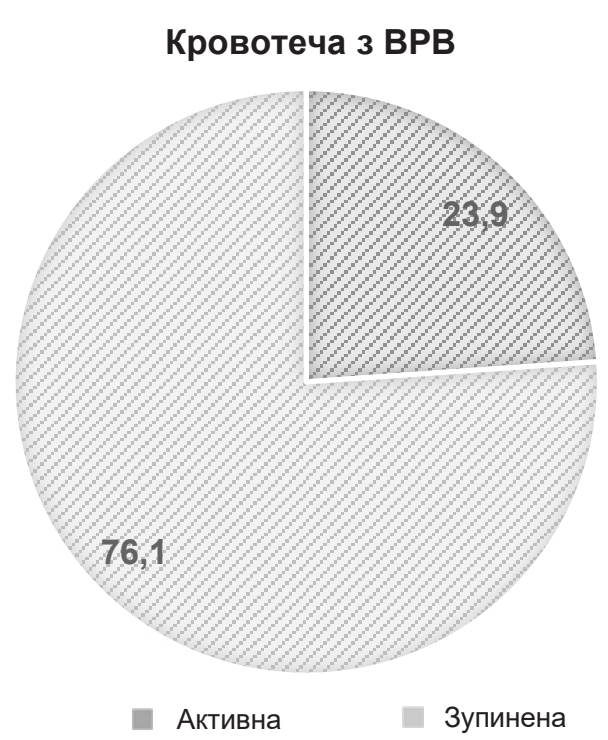

Рис. 1. Активність кровотечі з варикозно розширених вен у пацієнтів із ХВГС на момент госпіталізації в стаціонар.
1998 р.) [6]. Ступінь крововтрати в даної категорії хворих розподілився так: мінімальна - в 13 випадках (28,3 \%), середня - в 16 (34,8 \%), велика і масивна - в 8 (17,4 \%) і 9 (19,6 \%), відповідно (рис. 2).

Аналіз супутньої патології встановив, що у пацієнтів із ХВГС поряд із портальною гіпертензією, ускладненою кровотечею з варикозно розширених вен стравоходу, виявлено кардіоваскулярну патологію в 31 випадку (67,4 \%). За нозологіями: IXC: атеросклеротичний кардіосклероз у 8 хворих (17,4 \%); IXC: дифузний кардіосклероз у 10 (21,7 \%); гіпертонічна хвороба II ст. у 11 пацієнтів (23,9 \%); серцева недостатність у 2 (4,4 \%). Захворювання ендокринної системи виявлено в 5 випадках (10,9 \%): цукровий діабет 1 типу - 1 (2,2 \%), 2 типу - 4 (8,7 \%). Інфекційні захворювання (ВІЛ-інфекція) виявлено в 3 випадках (6,5 \%). Онкопатологію (рак печінки) виявлено у 2 хворих (4,4 \%). Супутню патологію не діагностовано в 20 випадках (43,5 \%) (рис. 3).

Усім пацієнтам проведено оцінку функціонального стану печінки з використанням клініколабораторних методів. Залежно від показників рівня трансаміназ і білірубіну всі хворі розподілені на 3 групи: перша - показники знаходяться в межах референсних значень $\left(\mathrm{n}_{1}\right)$, друга - показники перевищують референсні значення не більш ніж у 2 рази $\left(\mathrm{n}_{2}\right)$; третя - 3 двократним і більше перевищенням норми $\left(\mathrm{n}_{3}\right)$. Проведено оцінку отриманих даних методом розрахунку t-критерію Стьюдента для визначення статистичної значущості.

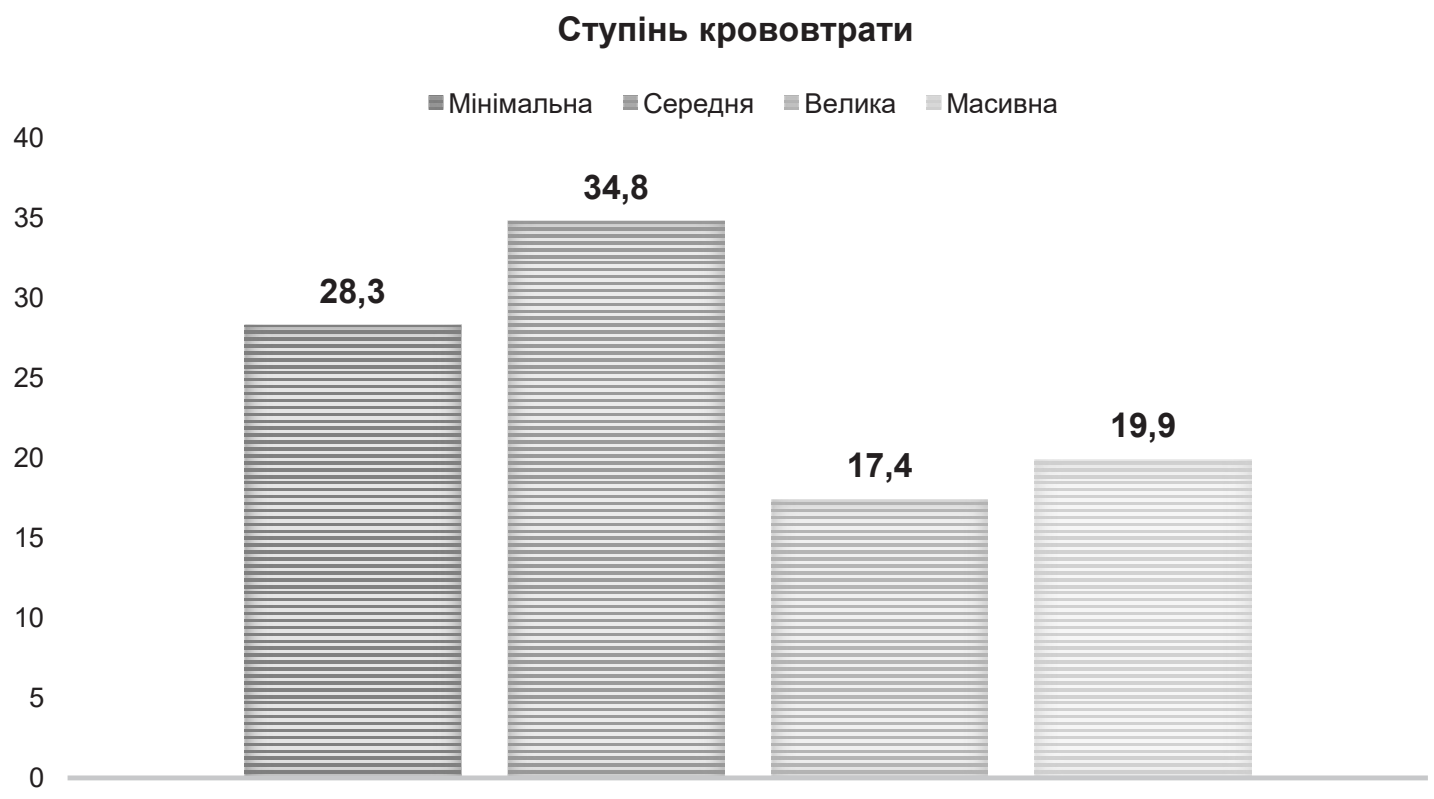

Рис. 2. Ступінь крововтрати у пацієнтів із варикозно розширених вен на фоні прогресування хронічного вірусного гепатиту С. 


\section{Супутня патологія}

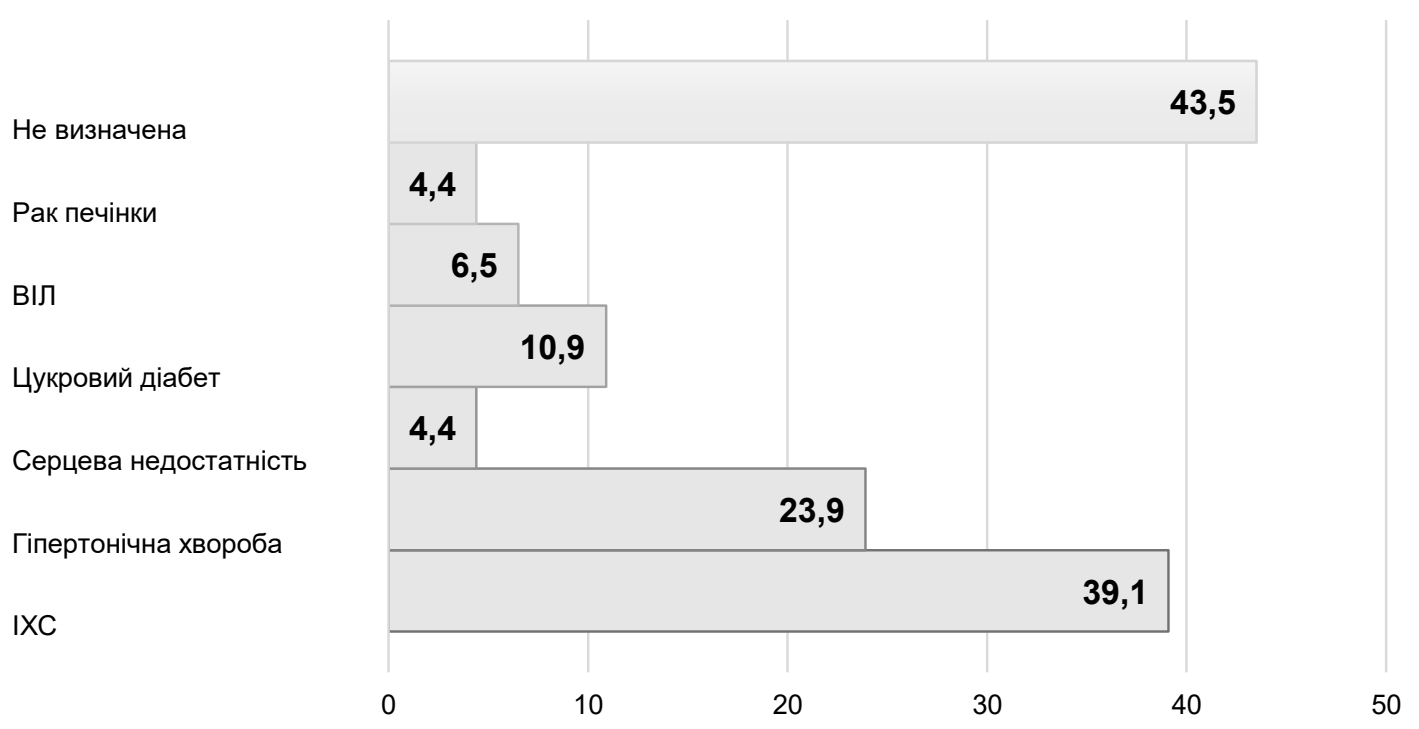

Рис. 3. Супутня патологія у пацієнтів із варикозно розширених вен на фоні прогресування хронічного вірусного гепатиту C.

Встановлено, що з огляду на рівень вмісту загального білірубіну в сироватці крові до першої групи пацієнтів $\left(\mathrm{n}_{1}\right)$ віднесено 22 (47,8 \%), середній показник $\left(\mathrm{M}_{1}\right)$ становив $(15,06 \pm 0,65)$ мкмоль/л. Перевищення рівня білірубіну менш ніж у 2 рази $\left(\mathrm{n}_{2}\right)$ встановлено в 14 хворих (30,4 \%), середнє значення $\left(\mathrm{M}_{2}\right)(28,39 \pm 2,11)$ мкмоль/л. У 10 пацієнтів $(21,7 \%)$ виявлено підвищення рівня білірубіну більш ніж у 2 рази $\left(\mathrm{n}_{3}\right)$, середній показник $\left(\mathrm{M}_{3}\right)$ склав $(58,78 \pm 8,59)$ мкмоль/л (табл. 1).

Проведено розрахунок t-критерію для кожної 3 трьох груп пацієнтів $\left(\mathrm{n}_{1}, \mathrm{n}_{2}, \mathrm{n}_{3}\right)$. На підставі статистичного аналізу отриманих даних із результатами, виявленими при обстеженні групи добро- вольців $\left(\mathrm{n}_{0}\right)$, встановлено, що спостерігаються відмінності статистично значущі (рівень значущості $\mathrm{p}<0,05)$.

Аналіз рівня трансфераз у хворих на ХВГС, що ускладнився кровотечею з ВРВ, виявив, що показники АЛТ в межах референсних значень $\left(\mathrm{n}_{1}\right)$ встановлено в 29 випадках (63,1 \%), середній показник $\left(\mathrm{M}_{1}\right)$ становив $(0,49 \pm 0,02)$ мкмоль (л×год). Підвищення показника менш ніж у два рази $\left(\mathrm{n}_{2}\right)$ встановлено у 12 випадках (26,1 \%), середнє значення $\left(\mathrm{M}_{2}\right)-(0,9 \pm 0,05)$ мкмоль (л×год). Більш ніж у 2 рази підвищення рівня трансферази $\left(\mathrm{n}_{3}\right)$ встановлено в 5 випадках (10,8 \%), середній показник $\left(\mathrm{M}_{3}\right)$ склав $(2,21 \pm 0,49)$ мкмоль (л×год) (табл. 2).

Таблиця 1. Розподіл пацієнтів із варикозним розширенням вен на фоні прогресування хронічного вірусного гепатиту С за рівнем білірубіну

\begin{tabular}{|c|c|c|c|c|}
\hline \multirow{3}{*}{$\begin{array}{c}\text { Розподіл хворих } \\
\text { за рівнем білірубіну }\end{array}$} & \multicolumn{3}{|c|}{ Групи, рівень білірубіну, мкмоль/л } & \multirow{3}{*}{$\begin{array}{c}\text { Група } \\
\text { порівняння }\end{array}$} \\
\hline & 1 & 2 & 3 & \\
\hline & $8,5-20,5$ & $20,5-41$ & $>41,0$ & \\
\hline $\begin{array}{l}\text { Средні показники } \\
\text { білірубіну (М), мкмоль/л }\end{array}$ & $15,06 \pm 0,65$ & $28,39 \pm 2,11$ & $58,78 \pm 8,59$ & $10,62 \pm 0,42$ \\
\hline Абс. кількість хворих & $\mathrm{n}_{1}-22$ & $\mathrm{n}_{2}-14$ & $\mathrm{n}_{3}-10$ & $\mathrm{n}_{0}-45$ \\
\hline Відсоток хворих & 47,8 & 30,4 & 21,7 & - \\
\hline t-критерій & 5,74 & 8,26 & 5,60 & - \\
\hline Рівень значущості & $\mathrm{p}<0,05$ & $\mathrm{p}<0,05$ & $\mathrm{p}<0,05$ & - \\
\hline
\end{tabular}


Таблиця 2. Розподіл пацієнтів із варикозним розширенням вен на фоні прогресування хронічного вірусного гепатиту С за рівнем АЛТ

\begin{tabular}{||c|c|c|c|c||}
\hline \multirow{2}{*}{$\begin{array}{c}\text { Розподіл хворих за рівнем } \\
\text { АЛТ }\end{array}$} & \multicolumn{3}{|c||}{ Групи, рівень АЛТ, мкмоль (лхгод) } & \multirow{2}{*}{$\begin{array}{c}\text { Група } \\
\text { порівняння }\end{array}$} \\
\cline { 2 - 4 } & 1 & 2 & 3 & $>1,39$ \\
\hline $\begin{array}{l}\text { Средні показники АЛТ } \\
\text { (М), мкмоль (л×год) }\end{array}$ & $0,1-0,68$ & $0,68-1,39$ & $2,21 \pm 0,49$ & $0,3 \pm 0,02$ \\
\hline Абс. кількість хворих & $\mathrm{n}_{1}-29$ & $0,9 \pm 0,05$ & $\mathrm{n}_{3}-5$ & $\mathrm{n}_{0}-45$ \\
\hline Відсоток хворих & 63,1 & $\mathrm{n}_{2}-12$ & 10,8 & - \\
\hline t-критерій & 6,72 & 26,1 & 3,89 & - \\
\hline Рівень значущості & $\mathrm{p}<0,05$ & 11,14 & $\mathrm{p}<0,05$ & - \\
\hline
\end{tabular}

Проведено розрахунок t-критерію для кожної з трьох груп пацієнтів $\left(\mathrm{n}_{1}, \mathrm{n}_{2}, \mathrm{n}_{3}\right)$. На підставі статистичного аналізу отриманих даних із результатами, виявленими при обстеженні контрольної групи добровольців $\left(\mathrm{n}_{0}\right)$ встановлено що статистично значущі відмінності (рівень значущості $\mathrm{p}<0,05)$.

Проведено оцінку печінкової недостатності за класифікацією Чайлд-П’ю. Недостатність ступеня А діагностовано у 23 пацієнтів (50\%), ступінь В - у 16 (34,8 \%), ступінь С - у 7 (15,2 \%) (рис. 4).
Печінкова недостатність

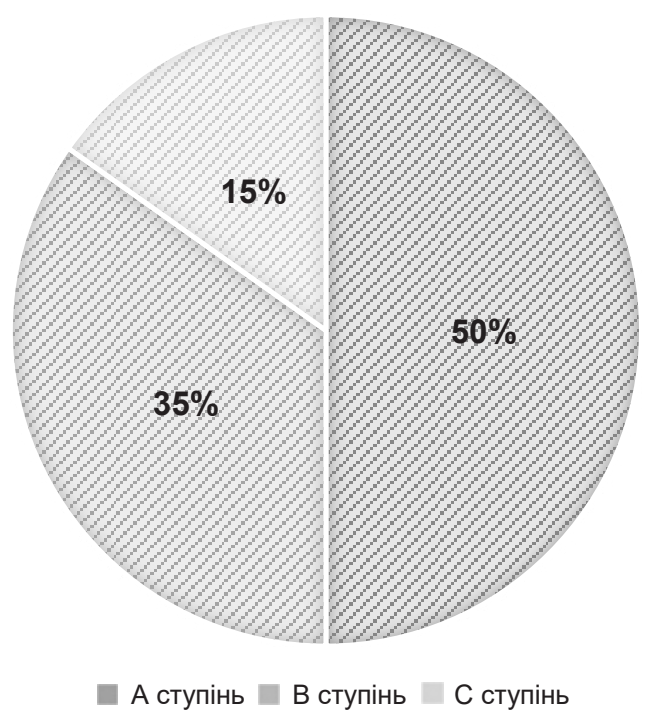

Рис. 4. Ступінь печінкової недостатності за класифікацією Чайлд-П'ю в пацієнтів із варикозним розширенням вен на фоні прогресування хронічного вірусного гепатиту C.
Наявність вільної рідини в черевній порожнині як маркер декомпенсації печінкової недостатності в пацієнтів із ХВГС встановлено в 28 випадках (60,9 \%). У 18 пацієнтів асцит не спостерігали (39,1\%) (рис. 5).

Всім госпіталізованим хворим проведено лікування в умовах хірургічного стаціонару. За результатами лікування 36 хворих (78,3 \%) виписали з поліпшенням, в 10 епізодах (21,7 \%) спостерігали летальний результат (рис. 6).

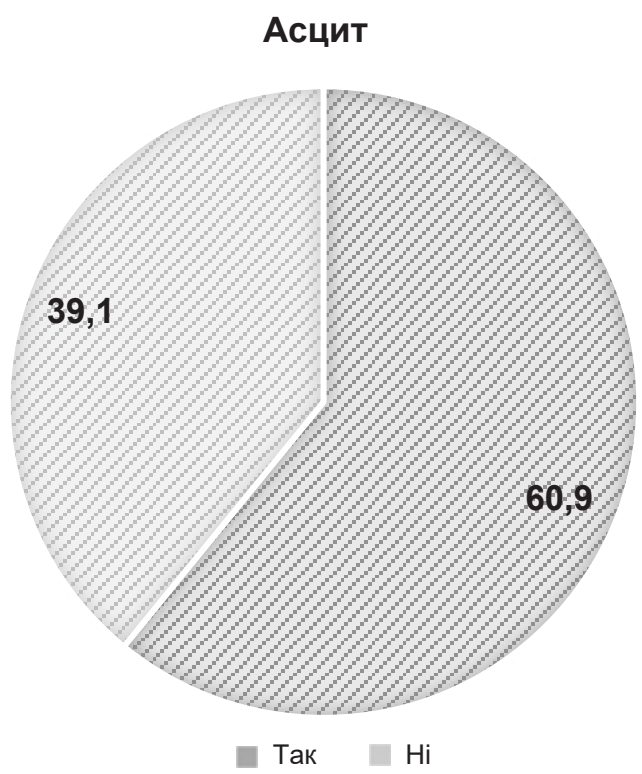

Рис. 5. Наявність асциту в пацієнтів із варикозним розширенням вен на фоні прогресування хронічного вірусного гепатиту С. 


\section{Результат лікування}

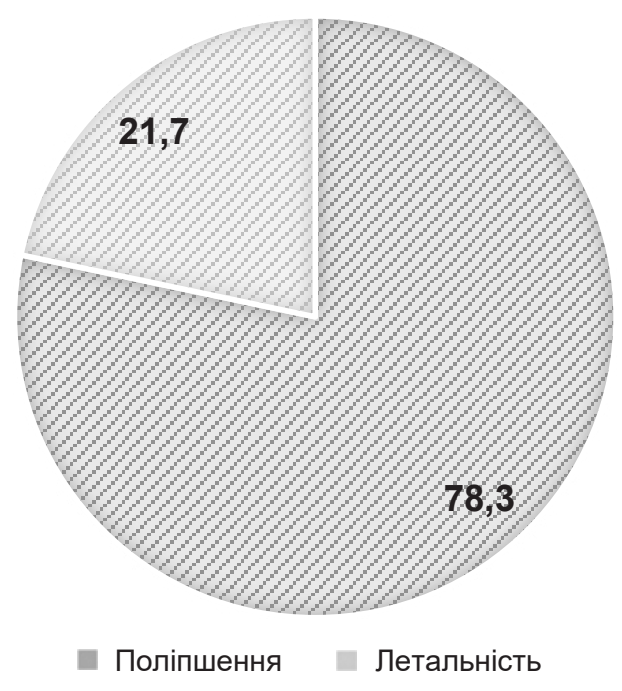

Рис. 6. Результати лікування пацієнтів із кровотечею з варикозно розширених вен на фоні прогресування хронічного вірусного гепатиту C.

Висновки. 1. Основною причиною виникнення кровотечі з варикозно розширених вен стравоходу є цироз печінки, що розвинувся на фоні вірусного гепатиту C (48,4 \% випадків).

\section{СПИСОК ЛІТЕРАТУРИ}

1. de Franchis R. Evolving consensus in portal hypertension report of the Baveno IV consensus workshop on methodology of diagnosis and therapy in portal hypertension / R. de Franchis // J. Hepatol. - 2005. - Vol. 43 (1). - P. 167-176.

2. Incidence and natural history of small esophageal varices in cirrhotic patients / M. Merli, G. Nicolini, S. Angeloni [et al.] // J. Hepatol. - 2003. - Vol. 38 (3). - P. 266-272.

3. Shepard C. W. Global epidemiology of hepatitis C virus infection / C. W. Shepard, L. Finelli, M. J. Alter // Lancet Infect. Dis. - 2005. - Vol. 5 (9). - P. 558-567.

\section{REFERENCES}

1. de Franchis, R. (2005). Evolving consensus in portal hypertension report of the Baveno IV consensus workshop on methodology of diagnosis and therapy in portal hypertension. J. Hepatol., 43 (1), 167-176. DOI: 10.1016/j.jhep.2005.05.009.

2. Merli, M., Nicolini, G., Angeloni, S., Rinaldi, V., De Santis, A., Merkel, C., ..., \& Riggio, O. (2003). Incidence and natural history of small esophageal varices in cirrhotic patients. J. Hepatol., 38 (3), 266-272. DOI: 10.1016/s0168-8278(02)00420-8.

3. Shepard, C.W., Finelli, L., \& Alter, M.J. (2005). Global epidemiology of hepatitis C virus infection. Lancet Infect. Dis., 5 (9), 558-567. DOI: 10.1016/S1473-3099(05)70216-4.
2. Оцінка функціонального стану печінки хворих із кровотечею з варикозно розширених вен стравоходу на фоні ХВГС встановила, що показники в межах референсних значень за рівнем білірубіну та трансфераз спостерігались майже в половині випадків (білірубін у 47,8 \% пацієнтів ( $<<0,05)$, рівень АЛТ у 63,1 \% пацієнтів $(\mathrm{p}<0,05))$. Печінкова недостатність ступеня А за класифікацією Чайлд-П’ю встановлена у 50 \% хворих.

3. Встановлено, що рівень летальності при кровотечах із варикозно-розширених вен стравоходу в пацієнтів із хронічним вірусним гепатитом С становить 21,7 \%, що відповідає середньосвітовий тенденції.

4. Отримані дані змушують нас вдосконалити існуючі методики прогнозування розвитку кровотечі з ВРВ на фоні хронічного вірусного гепатиту С, лікування даної патології та профілактики виникнення рецидиву.

Перспективи подальших досліджень. Проведене дослідження підтверджує, що сучасні методи оцінки функціонального стану печінки не відображають повною мірою виразність синдрому портальної гіпертензії в пацієнтів із вірусним гепатитом С. Це надихає нас на пошук більш інформативних неінвазивних методів оцінки портальної гіпертензії і ризику виникнення кровотечі з ВРВ у пацієнтів із ХВГС.

4. Estimating progression to cirrhosis in chronic hepatitis $\mathrm{C}$ virus infection / A. J. Freeman, G. J. Dore, M. U. Law [et al.] // Hepatology. - 2001. - Vol. 34 (4 Pt 1). - P. 809-816.

5. Simple blood tests as noninvasive markers of liver fibrosis in hemodialysis patients with chronic hepatitis C virus infection / L. L. Schiavon, J. L. Schiavon, R. J. Filho [et al.] // Hepatology. 2007. - Vol. 46 (2). - P. 307-314.

6. Marino P. L. The ICU Book. Hemodynamic monitoring / P. L. Marino. - Philadelphia: Lippincott Williams \& Wilkins, 2007.

4. Freeman, A.J., Dore, G.J., Law, M.Г., Thorpe, M., Von Overbeck, J., Lloyd, A.R., ..., \& Kaldor, J.M. (2001). Estimating progression to cirrhosis in chronic hepatitis $\mathrm{C}$ virus infection. Hepatology, 34 (4 Pt 1), 809-816. DOI: 10.1053/jhep.2001.27831.

5. Schiavon, L.L., Schiavon, J.L., Filho, R.J., Sampaio, J.P., Lanzoni, V.P., Silva, A.E., \& Ferraz, M.L. (2007). Simple blood tests as noninvasive markers of liver fibrosis in hemodialysis patients with chronic hepatitis $C$ virus infection. Hepatology, 46 (2), 307-314. DOI: 10.1002/hep.21681.

6. Marino, P. L. (2007). The ICU Book. Hemodynamic monitoring. Philadelphia: Lippincott Williams \& Wilkins. 
Dnipro State Medical University

\title{
CLINICAL AND STATISTICAL ASPECTS OF THE DEVELOPMENT AND COURSE OF BLEEDING FROM VARICOSE VEINS OF THE ESOPHAGUS IN PATIENTS WITH CHRONIC VIRAL HEPATITIS
}

\begin{abstract}
The aim of the work: to determine the features of the course of portal hypertension complicated by bleeding from varicose veins of the esophagus in patients with chronic viral hepatitis C.

Materials and Methods. We collected, processed and analyzed the results of treatment of 46 patients with bleeding from varicose veins of the esophagus (VVE) hospitalized in Dnipro Clinical Ambulance for 2017. The main etiological factor that led to the development of portal hypertension in this group of patients was cirrhosis of the liver on the background of chronic viral hepatitis C. The degree of blood loss in this category of patients was distributed as follows: minimal - in 13 cases (28.3\%), medium - in 16 (34.8 \%), large and massive - in 8 (17.4\%) and 9 (19.6\%) respectively.

All patients underwent assessment of liver function using clinical and laboratory methods.

Results and Discussion. It was found that the level of total bilirubin in the serum of 22 (47.8\%) patients was within the reference values, the level was exceeded less than 2 times in 14 patients (30.4\%), in 10 cases (21.7\%) revealed an increase in bilirubin by more than 2 times.

Analysis of the level of transferases in patients with HCV complicated by bleeding from varicose veins revealed that ALT within the reference values were detected in 29 cases (63.1\%), an increase of less than twice (n2) was observed in 12 cases (26.1\%), more than double the level of transferase was found in 5 cases $(10.8 \%)$.

Liver failure was assessed according to the Child-Pugh classification. It was found that grade A deficiency was observed in 23 patients (50 \%), grade B - in 16 (34.8\%), grade C - in 7 (15.2 \%).
\end{abstract}

As a result of the treatment, 36 patients (78.3\%) were discharged with improvement, in 10 episodes (21.7 \%) there was a lethal outcome.

Key words: chronic viral hepatitis C; esophageal varices; upper gastrointestinal bleeding; portal hypertension.

М. В. ТРОФИМОВ, Б. В. ГУЗЕНКО, С. И. БАРАННИК, В. В. ГРОМОВ

Днепровский государственный медицинский университет, Днепр

\section{КЛИНИКО-СТАТИСТИЧЕСКИЕ АСПЕКТЫ РАЗВИТИЯ И ТЕЧЕНИЯ КРОВОТЕЧЕНИЙ ИЗ ВАРИКОЗНО РАСШИРЕННЫХ ВЕН ПИЩЕВОДА У ПАЦИЕНТОВ С ХРОНИЧЕСКИМ ВИРУСНЫМ ГЕПАТИТОМ С}

Цель работы: выявить особенности течения синдрома портальной гипертензии осложненного кровотечением из варикозно расширенных вен (ВРВ) у пациентов с хроническим вирусным гепатитом С.

Материалы и методы. Собраны, обработаны и проанализированы результаты лечения 46 пациентов с кровотечениями из ВРВ, госпитализированных в КНП “Днепровская клиническая больница скорой медицинской помощи” ДГС” за 2017 г. Основным этиологическим фактором, который привел к развитию портальной гипертензии в данной группе пациентов, установлен цирроз печени на фоне хронического вирусного гепатита С (ХВГС). Степень кровопотери данной категории больных распределилась следующим образом: минимальная - в 13 случаях (28,3 \%), средняя - в 16 (34,8 \%), большая и массивная - в 8 (17,4 \%) и $9(19,6 \%)$ в соответствии.

Всем пациентам проведена оценка функционального состояния печени с использованием клинико-лабораторных методов. Результаты исследований и их обсуждение. Установлено, что уровень содержания общего билирубина в сыворотке крови у 22 (47,8 \%) пациентов находился в пределах референсных показателей, превышение уровня менее чем в 2 раза отмечено у 14 больных (30,4 \%), в 10 случаях (21,7 \%) выявлено повышение уровня билирубина более чем в 2 раза.

Анализ уровня трансфераз у больных ХВГС осложнившимся кровотечением из ВРВ выявил, что показатели АЛТ в пределах референсных значений обнаружены в 29 случаях (63,1 \%), повышение показателя меньше чем в 2 раза ( $\left.\mathrm{n}_{2}\right)$ отмечено в 12 случаях (26,1 \%), более чем в два раза повышение уровня трансфераз установлено в 5 случаях (10,8 \%).

Проведена оценка печеночной недостаточности по классификации Чайлд-Пью. Установлено, что недостаточность степени А отмечалась у 23 пациентов (50 \%), степень В - у 16 (34,8 \%), степень С - 7 (15,2 \%).

В результате проведенного лечения 36 больных (78,3 \%) выписаны с улучшением, в 10 эпизодах (21,7 \%) наблюдался летальный исход.

Ключевые слова: хронический вирусный гепатит С; варикозно-расширенные вены пищевода; кровотечение из верхних отделов желудочно-кишечного тракта; портальная гипертензия. 